\title{
PROFIL STABILITAS EKSTRAK BUNGA ROSELLA (HIBISCUS SABDARIFFA) SEBAGAI KANDIDAT PEWARNA LIPSTIK
}

\author{
Dwiki Putra Sukma P*, Yuspian Nur, Jaka Fadraersada \\ Laboratorium Penelitian dan Pengembangan Kefarmasian "Farmaka Tropis", \\ Fakultas Farmasi, Universitas Mulawarman, Samarinda, Indonesia \\ *Email: Dwikiputra@hotmail.com
}

\begin{abstract}
Coloring agents are important composition in formulation and acceptability of lipstick. One of natural colorant which have similiarity with synthetic colorant is anthocyanin that bring colour like FD\&C Red .40 which is popular colorant in food and cosmetic industry. This research aims to get anthocyanin stability profile from rosella (Hibiscus sabdariffa) extract by four parameters: $\mathrm{pH}$, temperature, light and times storage. Rosella extract obtained by maceration with etanol 96\%. $1000 \mathrm{ppm}$ concentration rosella extract in aquadest used to examined colour degradation by four parameters. Colour degradation of anthocyanin determined by spectroscopy UV-Vis and data collected was analyzed by One Way ANOVA $(\mathrm{p}<0,05)$. Smallest degradation of $\mathrm{pH}$ effect is $55,83 \%$ at $\mathrm{pH} 4(\mathrm{p}=0.000)$, temperature effect is $2,15 \%$ at $8-15{ }^{\circ} \mathrm{C}(\mathrm{p}=0.000)$, light effect is $5,46 \%$ at light lamp for 3 hours $(\mathrm{p}=0.000)$. Times storage effect for 15 days caused $4,53 \%$ degradation $(\mathrm{p}=0.000)$.
\end{abstract}

Keywords: Anthocyanin, Lipstick, Natural Colorant, Rosella, Spectroscopy UV-Vis

\begin{abstract}
ABSTRAK
Pewarna merupakan bagian penting dalam formulasi serta aseptabilitas lipstik. Pewarna alami yang memiliki kemiripan dengan pewarna sintetik salah satunya berasal dari senyawa antosianin yang memiliki kemiripan dengan FD\&C Red .40 dan telah banyak digunakan oleh industri makanan dan kosmetik. Penelitian dilakukan untuk mengetahui profil stabilitas antosianin dari ekstrak bunga rosella (Hibiscus sabdariffa) terhadap beberapa parameter yaitu pengaruh $\mathrm{pH}$, suhu, cahaya dan lama waktu penyimpanan. Ekstrak bunga rosella diperoleh dengan metode maserasi dengan pelarut etanol $96 \%$. Ekstrak kering kemudian dilarutkan dalam aquades untuk membuat 1000 ppm ekstrak dan setelah diberi perlakuan diukur dengan metode spektroskopi UV-Vis kemudian data dianalisis statistik menggunakan One Way Anova $(\mathrm{p}<0,05)$. Degradasi terkecil dari masing-masing parameter yaitu pada pengaruh $\mathrm{pH} 4$ sebesar 55,83\% $(\mathrm{p}=0.000)$, pengaruh suhu $8-15{ }^{\circ} \mathrm{C}$ sebesar $2,15 \%(\mathrm{p}=0.000)$, pengaruh cahaya lampu selama 3 jam $5,46 \%$ $(\mathrm{p}=0.000)$ dan Lama penyimpanan selama 15 hari meyebabkan terjadinya degradasi antosianin sebesar 4,53\% ( $\mathrm{p}=0.000)$.
\end{abstract}

Kata Kunci: Antosianin, Lipstik, Pewarna Alami, Rosella, Spektroskopi UV-Vis 
DOI: https://doi.org/10.25026/mpc.v8i1.324

\section{PENDAHULUAN}

Lipstik adalah sediaan kosmetik yang digunakan untuk meningkatkan penampilan bibir melalui perubahan warna dan terkadang disertai efek berkilau. Lipstik umumnya mengandung basis dan pigmen sebagai pewarna. ${ }^{1}$

Berdasarkan Pers BPOM 3 tahun terakhir, lipstik menjadi produk kosmetik yang paling sering ditemui penggunaan bahan berbahaya dibandingkan produk kosmetik lain. Pers BPOM No. IN.05.03.1.43.11.15.5285 tahun 2015, menemukan 14 produk lipstik dari total 30 temuan, Pers BPOM No. IN 005.03.1.43.06.16.2848 tahun 2016, menemukan 14 produk lipstik dari total 43 temuan dan Pers BPOM No. BIN.05.03.1.43.12.17 tahun 2017, menemukan 17 produk lipstik dari total 26 temuan. Temuan pada produk lipstik mengandung bahan berbahaya yang sama yaitu bahan pewarna sintetik merah K3 dan merah K10 yang memiliki sifat karsinogenik dan dapat menimbulkan gangguan fungsi hati dan kanker hati sehingga penggunaannya dilarang dalam kosmetik.

Penelitian mengenai keamanan pewarna sintetik bahkan dengan grade FD\&C memiliki efek samping seperti FD\&C Blue No.1 dan 2 yang mampu menembus saluran cerna dan masuk ke aliran darah, FD\&C Red No.3 memiliki sifat karsinogenik pada hewan, FD\&C Red No.40 menyebabkan tumor pada hewan. $^{2}$

Pewarna alami merupakan alternatif karena lebih aman untuk digunakan bahkan untuk dikonsumsi, namun pewarna alami memiliki kekurangan yaitu kurang stabil terhadap pengaruh fisika dan kimia keseragaman warna kurang baik, konsentrasi pigmen rendah, spektrum warna terbatas. ${ }^{3}$
Antosianin merupakan salah satu pewarna alami yang tersebar luas pada tumbuhan. Pigmen yang berwarna kuat dan larut dalam air ini merupakan penyebab hampir semua warna merah jambu, merah marak, merah, ungu, dan biru dalam daun bunga, daun dan buah pada tumbuhan tingkat tinggi. ${ }^{4}$ Bagian bunga dari tumbuhan rosella (Hibiscus sabdariffa) yang banyak digunakan masyarakat sebagai minuman kesehatan memiliki kandungan 4 jenis antosianin yang terdiri dari hibiscin, gossypisianin, myrtillin dan krisantenin. $^{5}$

Ketidakstabilan pewarna alami dapat diminimalisir dengan mengatur kondisi yang sesuai, maka perlu dilakukan penelitian untuk mengetahui kondisi terbaik penyimpanan ektrak bunga rosella sehingga dapat dimanfaatkan lebih baik oleh masyarakat.

\section{METODE PENELITIAN}

\section{Bahan}

Etanol teknis 96\%, $\mathrm{NaOH}$ (Merck), $\mathrm{HCl}$ (Merck), aquades, natrium sitrat (Brataco), asam sitrat (Brataco). Bunga rosella (Hibiscus sabdariffa) diperoleh dari Loa Janan Ulu, Kota Samarinda, Provinsi Kalimantan Timur.

\section{Pembatan Simplisia}

Bunga rosella dikumpulkan kemudian dibersihkan dari pengotor, dirajang kecil kecil kemudian dikering anginkan ditempat yang terlindung cahaya matahari. ${ }^{6}$

\section{Metode Ekstraksi}

Sejumlah 150 gram simplisia bunga rosella dimaserasi dengan etanol 96\% selama 24 jam pada suhu kamar ditempat yang terlindung cahaya. Diuapkan pelarut hingga diperoleh ekstrak kental. ${ }^{7}$ 


\section{Uji Kualitatif Antosianin}

Ektrak dilarutkan dengan aquades kemudian diuji secara kualitatif. Ektrak yang positif mengandung antosianin akan menghasilkan warna biru kehijauan ketika ditambahkan $\mathrm{NaOH}$ tetes demi tetes dan warna akan bertahan merah ketika ditambahkan HCL dan dipanaskan pada suhu $100{ }^{\circ} \mathrm{C} .8$

\section{Penentuan Panjang Gelombang Maksimum}

Sejumlah 1000 ppm larutan ekstrak bunga rosella diukur absorbansinya pada panjang gelombang $475-550 \mathrm{~nm}^{7}$

\section{Pembuatan Buffer}

Sejumlah 10,505 gram asam sitrat dilarutkan dalam $500 \mathrm{~mL}$ dan 14,705 gram natrium sitrat dilarutkan dalam $500 \mathrm{~mL}$, kemudian dicampurkan larutan asam sitrat dan natrium sitrat sehingga diperoleh buffer $\mathrm{pH} 4$; $\mathrm{pH} 4,5 ; \mathrm{pH} 5 ; \mathrm{pH}$ 5,5; $\mathrm{pH} 6 .{ }^{9}$

\section{Stabilitas terhadap Pengaruh pH}

Sejumlah 1000 ppm larutan ekstrak dibuat menggunakan larutan buffer $\mathrm{pH} 4$; $\mathrm{pH} 4,5 ; \mathrm{pH}$ 5; pH 5,5 dan $\mathrm{pH} 6$ kemudian diukur dengan spektrofotometer UV-Vis menggunakan panjang gelombang maksimum yang diperoleh. ${ }^{10}$

\section{Stabilitas terhadap Pengaruh Suhu}

Sejumlah 1000 ppm larutan ekstrak dibuat menggunakan aquades kemudian dikondisikan pada suhu $8-15{ }^{\circ} \mathrm{C}, 15-30{ }^{\circ} \mathrm{C}$, 30-40 ${ }^{\circ} \mathrm{C}$ dan $70-80{ }^{\circ} \mathrm{C}$ selama 1 jam kemudian diukur dengan spektrofotometer $\mathrm{UV}-\mathrm{Vis}$ menggunakan panjang gelombang maksimum yang diperoleh. 10

\section{Stabilitas terhadap Pengaruh Cahaya}

Sejumlah 1000 ppm larutan ekstrak dibuat menggunakan aquades kemudian dikondisikan pada tempat dengan cahaya matahari, tempat dengan cahaya lampu dan tempat tanpa cahaya selama 6 jam dan dilakukan pengukuran setiap 3 jam dengan spektrofotometer UV-Vis menggunakan panjang gelombang maksimum yang diperoleh. ${ }^{10}$

\section{Stabilitas terhadap Pengaruh Lama Penyimpanan}

Sejumlah 1000 ppm larutan ekstrak dibuat dari ekstrak yang disimpan pada suhu $15-30^{\circ} \mathrm{C}$ menggunakan aquades kemudian diukur setiap hari selama 15 hari dengan spektrofotometer UV-Vis menggunakan panjang gelombang maksimum yang diperoleh. ${ }^{10}$

\section{Pengolahan Data}

Data yang diperoleh kemudian dihitung \% Degradasinya menggunakan rumus: ${ }^{11}$

Ketertangan:

$$
\% \mathrm{D}=\frac{\mathrm{A} 0-\mathrm{A} 1}{\mathrm{~A} 0} \times 100 \%
$$

$$
\begin{aligned}
& \% \mathrm{D}=\% \text { Degradasi } \\
& \mathrm{A} 0=
\end{aligned}
$$

\begin{tabular}{lcr}
\multicolumn{1}{c}{ Serta } & dianalisis & statistik \\
menggunakan & One Way & Anova \\
menggunakan & software IBM & SPSS \\
Statistics versi & 22 dengan nilai signifikasi \\
$0,05 \%$ &
\end{tabular}

\section{HASIL DAN PEMBAHASAN}

\section{Ekstraksi}

Proses ekstraksi untuk memperoleh bahan pewarna dari senyawa antosianin bunga rosella dilakukan dengan metode maserasi pada suhu kamar dan pelarut etanol 96\%. antosianin termasuk dalam golongan flavonoid. Senyawa golongan flavonoid termasuk senyawa polar sehingga ekstraksinya menggunakan pelarut polar pula. ${ }^{12}$ Pemilihan metode maserasi didasarkan pada ketidakstabilan antosianin terhadap panas. Ketika antosianin terpapar suhu pemanasan yang terlalu lama maka jumlah flavium pada antosianin menurun 
sehingga kesetimbangan akan bergeser ke bentuk kalkon hal ini menyebabkan penurunan warna dari ekstrak antosianin yang dihasilkan. Hal ini didukung penelitian suzery, metode maserasi pada suhu kamar dan pelarut etanol (1g sampel : $3 \mathrm{ml}$ pelarut) menghasilkan rendemen yang lebih banyak. $^{7}$ Berdasarkan ekstraksi yang dilakukan rendemen yang diperoleh adalah $11,07 \%$

\section{Uji Kualitatif}

Hasil uji kualitatif antosianin menggunakan $\mathrm{NaOH} 2 \mathrm{M}$ dan $\mathrm{HCl} 2 \mathrm{M}$ adalah pada tabel 1 .

Tabel 1. Hasil Uji Kualitatif

\begin{tabular}{lcl}
\hline \multicolumn{1}{c}{ Uji } & Hasil & \multicolumn{2}{c}{ Hasil Positif } \\
\hline $\mathrm{NaOH}$ & $(+)$ & \multicolumn{2}{l}{ Hijau kebiruan } \\
\hline $\mathrm{HCl}$ & $(+)$ & $\begin{array}{l}\text { Warna tidak } \\
\text { pudar }\end{array}$ \\
\hline
\end{tabular}

Keterangan:

$(+)=$ Mengandung Antosianin

\section{Stabilitas terhadap Pengaruh pH}

$\mathrm{pH} 4$ sampai 6 merupakan $\mathrm{pH}$ fisiologis kulit sehingga perlu digunakan dalam formulasi lipstik untuk menghindari terjadinya iritasi. $^{13}$ Berdasarkan gambar 1, degradasi terkecil terjadi pada $\mathrm{pH} 4$ yaitu 55,83\% dan terus meningkat seiring bertambahnya $\mathrm{pH}$. Semakin tingginya degradasi yang terjadi disebabkan oleh peningkatan jumlah basa karbinol. Basa karbinol akan terus meningkat seiring perubahan kearah $\mathrm{pH}$ basa semakin besar. ${ }^{14}$ Hidrasi flavium menjadi basa karbinol yang tidak berwarna terjadi di posisi C-2 pada struktur antosianin yang mengalami kehilangan ion $\mathrm{H}^{+}$dan penambahan $\mathrm{H}_{2} \mathrm{O}$. ${ }^{15}$

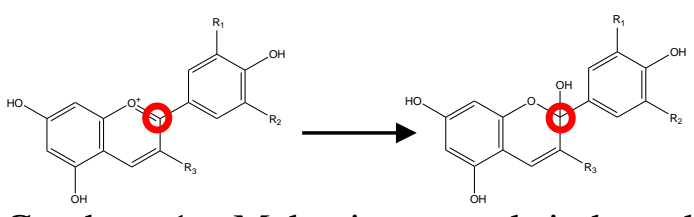

Gambar 1. Mekanisme reaksi bentuk antosianin kation flavium menjadi basa karbinol

$\begin{array}{rrrr}\text { Pada } & \mathrm{pH} & \text { asam antosianin } \\ \text { memiliki jumlah } & \text { flavium lebih }\end{array}$ mendominasi sedangkan pada $\mathrm{pH}$ basa quinodal dan karbinol lebih mendominasi (Fatonah, 2011). Berdasarkan analisis statistik One Way ANOVA terdapat perbedaan signifikan $(0,00)$ dengan nilai signifikansi $\mathrm{p}<0,05$ dari setiap pengaruh $\mathrm{pH}$. Profil stabilitas terhadap pengaruh $\mathrm{pH}$ menggunakan buffer sitrat adalah pada Gambar 2.

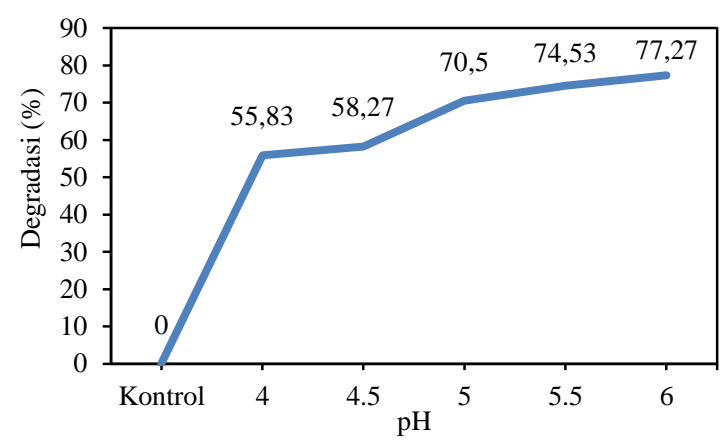

Gambar 2. Stabilitas terhadap Pengaruh $\mathrm{pH}$

\section{Stabilitas terhadap Pengaruh Suhu}

Menurut Farmakope IV, Suhu 8$15{ }^{\circ} \mathrm{C}$ adalah suhu dingin, $15-30{ }^{\circ} \mathrm{C}$ adalah suhu kamar, dan suhu $30-40{ }^{\circ} \mathrm{C}$ adalah suhu panas. Suhu 70-80 merupakan suhu formulasi lipstik pada umumnya. Hasil penelitian pada gambar 3 menunjukkan bahwa semakin tinggi pengaruh suhu maka semakin tinggi pula $\%$ degradasi yang dialami. Perubahan warna yang diakibatkan suhu pemanasan bersifat irreversible, reaksi ini diawali dari terbukanya cincin flavium akibat 
pemanasan sehingga struktur antosianin berbentuk kalkon. ${ }^{16} \quad$ Kation

flavium yang telah berubah menjadi kalkon yang tidak berwarna tidak dapat kembali berwarna merah. ${ }^{17}$ Perubahan \% degradasi terbesar terjadi mulai suhu 30 $40{ }^{\circ} \mathrm{C}$ dan puncaknya pada suhu $70-80$ ${ }^{\circ} \mathrm{C}$. Hal ini diduga akibat semakin banyaknya jumlah kalkon hasil dari dekomposisi antosianin pada bentuk aglikon dibandingkan kation flavium yang ada. Berdasarkan analisis statistik One Way ANOVA terdapat perbedaan signifikan $(0,00)$ dengan nilai signifikansi $\mathrm{p}<0,05$ dari setiap pengaruh suhu. Profil stabilitas antosianin terhadap pengaruh suhu adalah pada Gambar 3.

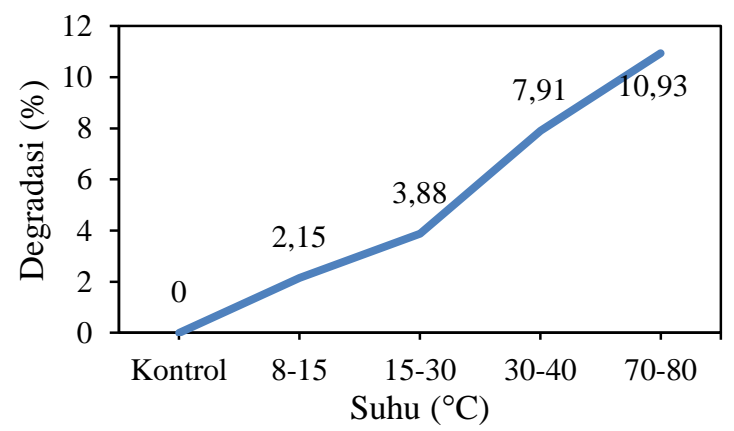

Gambar 3. Stabilitas terhadap Pengaruh Suhu

\section{Stabilitas terhadap Pengaruh Cahaya}

Jenis dan lama paparan cahaya mempengaruhi besar degradasi yang dialami antosianin. Hasil penelitian pada gambar 4 menunjukkan bahwa jenis cahaya dan lama penyinaran mempengaruhi besar degradasi yang terjadi pada warna antosianin dari ekstrak bunga rosella. Energi dari cahaya yang besar menyebabkan fotooksidase yang dapat membuka cincin flavium dari antosianin lebih besar, kemudian menyebabkan terbentuknya struktur kalkon yang tidak berwarna dari antosianin lebih banyak. ${ }^{18}$
Hal ini lah yang kemudian menyebabkan ekstrak bunga rosella yang diberi pengaruh cahaya matahari mengalami degradasi warna yang lebih besar daripada cahaya lampu. Berdasarkan analisis statistik One Way ANOVA terdapat perbedaan signifikan $(0,00)$ dengan nilai signifikansi $\mathrm{p}<0,05$ dari setiap pengaruh cahaya.Profil stabilitas antosianin terhadap pengaruh cahaya adalah pada Gambar 4.

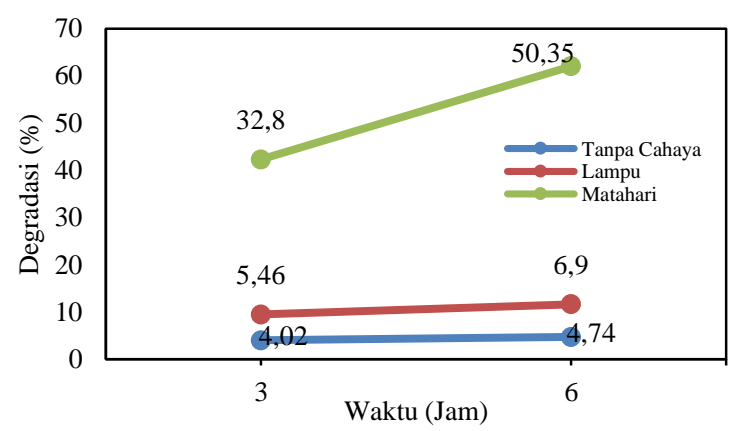

Gambar 4. Stabilitas terhadap Pengaruh Cahaya

\section{Stabilitas terhadap Lama Penyimpanan \\ Lama penyimpanan} mempengaruhi besar degradasi warna yang terjadi. Pada Gambar 5, terjadi degradasi hingga hari ke 15, warna dari produk kosmetik seharusnya tidak berubah selama 15 hari. ${ }^{19}$ Hal ini kemudian menjadi salah satu kekurangan pewarna alami dari antosianin ekstrak bunga rosella. Selain akibat kesetimbangan flavium yang bergeser ke bentuk karbinol dan kalkon, terjadinya degradasi pada lama penyimpanan juga dari faktor lain seperti pertumbuhan mikroorganisme yang mampu mendekomposisi antosianin. Berdasarkan analisis statistik One Way ANOVA terdapat perbedaan signifikan $(0,00)$ dengan nilai signifikansi $\mathrm{p}<0,05$ dari setiap pengaruh lama penyimpanan. 
Profil stabilitas antosianin terhadap lama penyimpanan adalah pada Gambar 5 .

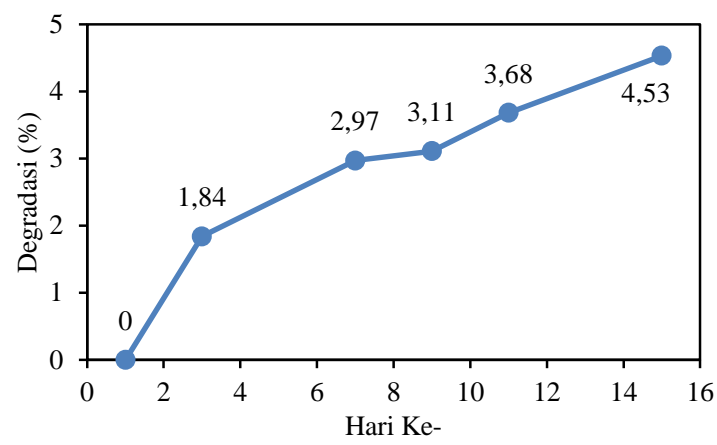

Gambar 5. Stabilitas terhadap Lama Penyimpanan

\section{KESIMPULAN DAN SARAN}

Berdasarkan penelitian yang telah dilakukan rendemen yang diperoleh dari ekstrak bunga rosella menggunakan metode maserasi dan pelarut etanol adalah $11,07 \%$, ekstrak yang diperoleh positif mengandung antosianin dengan uji kualitatif. kondisi terbaik dalam penyimpanan serta formulasi lipstik dari pewarna alami ekstrak bunga rosella adalah pada suhu $\left(8-15{ }^{\circ} \mathrm{C}\right)$ dan $\mathrm{pH}$ serendah mungkin $(\mathrm{pH} 4)$, ditempat yang terlindung cahaya serta menghindari penyimpanan yang terlalu lama. Saran penulis untuk penelitian ini adalah agar selalu menjaga kebersihan tempat kerja dan mengurangi kontak sampel dengan udara maupun cahaya sehingga dapat mencegah kontaminasi dan menghasilkan data yang maksimal.

\section{DAFTAR PUSTAKA}

[1] Baki, G., dan Alexander, Kenn. S. 2015. Introduction to Cosmetic Formulation and Technology. Canada: John Wiley \& Sons, Inc.

[2] Kumar, Manish., Venkatesh, MP., Kumar Pramod. 2017. Colourants and Additives: Existing and Emerging Safety Concerns. International Journal of
Pharmaceutical and Clinical Research 2017; 9(7): 525-533

[3] Paryanto, Purwanto, A., Kwartiningsih, E., dan Mastuti, E. 2012. Pembuatan Zat warna Alami dalam Bentuk Serbuk untuk Mendukung Industri Batik di Indonesia. Jurnal Rekayasa Proses, Volume 6 No.1.

[4] Bechtold, Thomas., dan Rita Mussak. Handbook of Natural Colorants. Canada: A John Wiley and Sons, Inc.

[5] Da-Costa-Rocha, Inês., Bernd Bonnlaender., Hartwig Sievers., Ivo Pischel., dan Michael einrich. 2014. Hibiscus sabdariffa L. $\quad-$ A phytochemical and pharmacological review. Journal Food Chemistry Elsevier Volume 165.

[6] Rahayu, Wiranti Sri., Hartansi, Dewi., Hidayat, Nasrun. 2009. Pengaruh Metode Pengeringan Terhadap Kadar Antosianin pada Kelopak Bunga Rosella (Hibiscus sabdariffa). Jurnal Pharmacy Volume 06 No.02

[7] Suzery, Meiny., Sri Lestari dan Bambang Cahyono. 2010. Penentuan Total Antosiain dari Kelopak Bunga Rosela (Hibiscus Sabdariffa L) dengan Metode Maserasi dan Sokshletasi. Jurnal sains dan matematika Volume 18 No.1.

[8] Harborne, J.B., 1996. Metode Fitokimia Penuntun Cara Modern Menganalisis. Tumbuhan. Bandung: ITB.

[9] Mohan, Chandra. 2006. Buffers: A guide for the preparation and use of buffers in biological systems. California: EMD.

[10] Mayasari, Dewi., Taofik Rusdiana, Yulien Ratu Kania dan Marline Abdasah. 2018. Stabilitas Ekstrak Umbi Bawang Tiwai (Eleutherine americana (L.) Merr.) sebagai Pewarna Lipstik terhadap Perubahan Suhu, Waktu, Kondisi Penyimpanan, $p H$ dan Adanya Oksidator. Indonesian Journal of 
Pharmaceutical Science and Technology Volume 5 No.1.

[11]Fendri, Sandra Tri Juli., Martinus, B.A,. Haryanti, Meindika Dewi,. 2018. Pengaruh pH dan Suhu Terhadap Stabilitas Antosianin dari Ekstrak Kulit Ubi Jalar Ungu (Ipomoea batatas). Chempublish Journal.Volume 2 No. 2

[12] Ingrath, Windha., Wahyunanto Agung Nugroho dan Rini Yulianingsih. 2015. Ekstraksi Pigmen Antosianin dari Kulit Buah Naga Merah (Hylocereus Costaricensis) Sebagai Pewarna Alami Makanan dengan Menggunakan Microwave (Kajian Waktu Pemanasan Dengan Microwave dan Penambahan Rasio Pelarut Aquades dan Asam Sitrat). Jurnal Bioproses Komoditas Tropis Volume 3 No.3.

[13]Ali, S.M., dan Yosipovitch, G., 2013. Skin pH: From Basic Science to Basic Skin Care, Acta Derm Venereol. 93: 261 -267.

[14]Devi, Suganya., Reshmi, S.K. 2012. The Effect of Light, Temperature,
$\mathrm{pH}$ On Stability of Pigments in Basella Alba Fruit. Asian Journal of Pharmaceutical and Clinical Research.Volume 5. Issue 4.

[15] He, Jian dan Aguisti, Monica. 2010. Anthocyanins: Natural Colorants with Health-Promoting Properties. Review of Food and Science Technology. Ohio State University.

[16]Patras, Ankit., Brunton, Nigel., Donnel, Colm dan Tiwari, B.K. 2010. Effect of thermal processing on anthocyanin stability in foods; mechanisms and kinetics of degradation. Elsevier Trends in Food Science \& Technology 21.

[17] Armanzah, Raynaldi Syarief dan Hendrawati, Tri Yuni., 2016. Pengaruh Waktu Maserasi Zat Antosianin sebagai Pewarna Alami Dari Ubi Jalar Ungu (Ipomoea batatas). Jurnal UMJ. TK-019.

[18] Andarwulan, N. dan Fitri, F., 2012. Pewarna Alami Untuk Pangan, Bogor: Institut Pertanian Bogor.

[19]Anvisa. 2005. Cosmetic Products Stability Guide. Brazil: National Health Surveillance Agency Press. 